\title{
Does the Law Determine What Heritage to Remember?
}

\author{
Marie-Sophie de Clippele ${ }^{1}$
}

Accepted: 22 December 2020 / Published online: 4 January 2021

(c) The Author(s) 2021

\begin{abstract}
Cultural heritage can offer tangible and intangible traces of the past. A past that shapes cultural identity, but also a past from which one sometimes wishes to detach oneself and which nevertheless needs to be remembered, even commemorated. These themes of memory, history and oblivion are examined by the philosopher Paul Ricoeur in his work La mémoire, l'histoire, l'oubli (2000). Inspired by these ideas, this paper analyses how they are closely linked to cultural heritage. Heritage serves as a support for memory, even if it can be mishandled, which in turn can affect heritage policies. Memory and heritage can be abused as a result of wounds from the past or for reasons of ideological manipulation or because of a political will to force people to remember. Furthermore, heritage, as a vehicule of memory, contributes to historical knowledge, but can remain marked by a certain form of subjectivism during the heritage and conservation operation, for which heritage professionals (representatives of the public authority or other experts) are responsible. Yet, the responsibility for conserving cultural heritage also implies the need to avoid any loss of heritage, and to fight against oblivion. Nonetheless, this struggle cannot become totalitarian, nor can it deprive the community of a sometimes salutary oblivion to its own identity construction. These theoretical and philosophical concepts shall be examined in the light of legal discourse, and in particular in Belgian legislation regarding cultural heritage. It is clear that the shift from monument to heritage broadens the legal scope and consequently raises the question of who gets to decide what is considered heritage according to the law, and whether there is something such as a collective human right to cultural heritage. Nonetheless, this broadening of the legislation extends the State intervention into cultural heritage, which in turn entails certain risks, as will be analysed with Belgium's colonial heritage.
\end{abstract}

Keywords Cultural heritage $\cdot$ Memory $\cdot$ History $\cdot$ Oblivion $\cdot$ Cultural heritage law · Colonial heritage

Marie-Sophie de Clippele

marie-sophie.declippele@usaintlouis.be

1 Université Saint-Louis - Bruxelles, Boulevard du Jardin botanique 43, 1000 Brussels, Belgium 
What cultural heritage should be remembered? What is to be protected and promoted and who gets to decide? Traditionally, the State is perceived as the steward of cultural heritage, and therefore has the duty to protect it, notably by elaborating heritage policies, adopting legal measures and providing financial support. But how is it possible to regulate such complex matters, especially in a multicultural society where several cultural identities, and therefore several cultural heritages, coexist?

To have a better understanding of the law regulating cultural heritage protection, the themes of memory, history and oblivion as explored by the French philosopher Paul Ricoeur in La mémoire, l'histoire, l'oubli (2000) [1] will serve as a philosophical reference for this paper and set the theoretical framework against which the legal analysis will be conducted (1). According to Ricoeur, history results from a dialectic between memory and oblivion, as history could function as a middle ground between too much or too few memory. Like history, cultural heritage interacts with memory and oblivion: it offers tangible and intangible traces of the past, which is incumbent upon us to remember and to transmit to future generations.

This interplay between heritage, history and memory paves the way toward a critical analysis on how legislation has been drafted in order to protect cultural heritage (2). This paper will focus on Belgian cultural heritage law, and mainly on tangible cultural heritage (monuments, sites, archaeological artefacts, cultural objects, ...) as it is the area which is the most regulated, and raise the following questions: What cultural heritage possesses sufficient cultural interest for it to be protected, and on the basis of which criteria? Who is associated with the decision to protect such heritage? Is there something such as a human right to cultural heritage in the Belgian legal system? The issue of the legal scope and the definition of cultural heritage as well as the issue of participation in the protection procedure reveal how the State envisions heritage itself. It also sheds light on the role of the State in determining what heritage to protect and how to deal with it, as it has the sovereign power to do so, which might entail certain risks, especially for contested cultural heritage.

Some final thoughts will be shared about the recent evolutions surrounding Belgian's contested heritage, or as some call it "dark heritage" [2], specifically concerning the country's colonial past. One may then grasp the complexity of the work still needing to be done on our past (3).

Note that the author of this paper chose to translate into English and where applicable quoted writers in English for better readability. However, the official French version of legal texts are left as they are accompanied by an English translation. Furthermore, the notion of 'cultural heritage' and 'heritage' will be used interchangeably as they are both used to refer to a past which is to be preserved for the future. Even though cultural heritage stresses the cultural aspect more than the more general notion of heritage, the latter is equally used in the field. A striking example is the recent European Year of Cultural Heritage (2018), where the motto states: "Our heritage: where the past meets the future", jumping from cultural heritage to heritage alike [3]. 


\section{Heritage Steeped in History and Memory}

In some way, heritage offers a narrative of the past in order to transfer it to future generations. It brings a tangible support to the present memory of such narratives, by preserving physical remains of the past. Therefore, important lessons drawn from a critical approach to memory can be applied to heritage narratives, which can equally be abused and manipulated for other purposes (1.1.).

Unlike the search for a loyal memory of events, history seeks the truth of the past and pursues scientific methods to do so. Yet, historians can never be completely neutral, there is always an inherent subjectivity to historical knowledge. The same goes for research conducted by heritage professionals. Both disciplines share the same "responsibility towards the past" (1.2.).

Finally, the concept of oblivion, the forgotten part of memory and history, contains essential philosophical considerations for heritage preservation: what to protect? What not, and therefore what to forget? (1.3.)

\subsection{Heritage Supports Memory But Can Be Equally Abused}

In his phenomenology of memory (i.e. the study of structures of consciousness related to memory as experienced from the first-person point of view), Ricoeur looks into the notions of image and recollection ("souvenir") and asks whether "recollection is (...) a kind of image" [1: 53], as some sort of representation of the past. According to him, "imagination and memory [have] the presence of the absent as a common feature", but they are distinguished in that imagination is positioned outside of reality, whereas memory is positioned in an earlier reality [1: 53-54]. However, a recollection, put into an image, presupposes a reconstruction of reality. Memory and recollection are therefore structurally vulnerable, as their reliability may be questioned. Memory can indeed be abused in multiple ways because the thing remembered is absent and the only presence of the thing is through representation.

In that respect, heritage, or at least tangible heritage, can act as a bulwark against the loss of the thing remembered. Heritage might allow the memory to be formed with the help of material traces, that exist in reality, and limit the use of imagination to reconstruct memories. But heritage is not safe from abuse either, as monuments do not necessarily tell an objective and unambiguous story.

Referring to Aristotle and Plato, the French philosopher Paul Ricoeur distinguishes two types of memory: on the one hand, a sensitive memory, the so-called mnemonic, which is related to our emotions and comes back to us even if we would rather that it did not, and on the other hand, a memory functioning as a reminder, which actively seeks not to forget, the anamnesis or what he calls the exercised memory and which will be the focus of this section [1: 8-25],

Ricoeur then lists three types of abuse of the exercised memory: an impeded memory, a manipulated memory and a forced memory. For all three, parallels can be drawn to abuses in heritage. 
The impeded memory, at a pathological-therapeutic level, refers to a wounded or sick memory, made difficult to remember, following a traumatic experience [1: 83-97], Relying on psychoanalytical theories, the French philosopher observes traumatic memory not only at the level of the individual, but also at the level of collective memory, in which there are "stored symbolic wounds calling for healing" [1: 96]. For Ricoeur, it is at the level of collective memory that mourning and remembrance are intertwined, which are both necessary to avoid sinking into what Freud calls the "repetition compulsion" $[4,5]$. This is the case when there is too mисh memory, repeated with a "morose delight", as for funeral rehearsals [1: 96]. One might think of the Yasukuni Shrine in Tokyo, Japan, a temple that pays homage, through an annual ritual, to so-called 'war heroes', yet is considered a symbol of Japan's colonial and nationalist past. But also when there is too little memory, remembering may be impeded, fled of some with a "bad conscience" [1: 96], such as the denial in which some survivors of crimes or cultural massacres take refuge. A striking example is that of the history of slave trade and slavery, long suppressed and with no heritage space or place to remember. UNESCO recognized in 1994 the Slave Route Project in order to commemorate this very dark page of history, stating that: "Ignorance or concealment of major historical events constitutes an obstacle to mutual understanding, reconciliation and cooperation among peoples" [6]. These two extremes of impeded memory-overly present or painfully absent-lack critical perspective and fail to access recollection, which, between mourning and remembrance, allows a society to reconcile itself in a peaceful way with its past.

In this regard, tangible cultural heritage, such as the Japanese Yasukuni Shrine or other mourning monuments, can be used to magnify a tragic past, thereby impeding a collective memory. But cultural heritage can on the contrary also play an essential role to help collective recollection and remembrance of a society, such as with the Slave Route Project or with creation of a museum on migration or on decolonisation. In The Past Is A Foreign Country, David Lowenthal already demonstrated in 1985 how history, memory and material remains of the past are used to make sense of the present, to such a point that it has given "rise to the modern cult of preservation and pervasive nostalgia" [7].

The manipulated memory, at a more practical level, and unlike wounded, submissive and sometimes passive memory, is the result of a "concerted manipulation of memory and oblivion by those in power" [1: 97]. Used as an instrument by political decision-makers, memory is mobilized "in the service of the quest, the request, the claim to identity" [1:98]. The imposed narrative (a founding narrative of glory and humiliation feeding the discourse of flattery and fear), acts as the main agent of ideologization.

Cultural heritage could in this context serve an ideology, in order to legitimize the authority of the order or power in place. Erecting statues is one of the most visible means to achieve this, it glorifies the deeds of political, military or religious leaders and quite literally puts them on a pedestal. In Belgium, statues were particularly popular in the 19th and early 20th century, such as those of King Leopold II or other industrial and military 'heroes' which were decorating the streets and celebrating a certain part of the country's colonial history, but at the same time obscuring another, 
that of the victims of such imperialism. In other words, "control of memory (...) is not the speciality of totalitarian regimes alone; it is the prerogative of all those who are zealous for glory"'[1: 104].

Referring to the work of the French-Bulgarian philosopher Tzvetan Todorov, Les abus de la mémoire, Ricoeur specifies that any reflection on the past implies selective sorting and thoughtful combination of events with each other, which will be "necessarily oriented by the search, not for truth, but for good"[8: 50]. Lowenthal also expresses the idea of a tractable past, confirming in a revised version of his book that we "celebrate, expunge, contest and domesticate" the past that we inherit, in order to reshape and bequeath the future [9].

Finally, at an ethical-political level, there is forced memory, which overlaps with the notion of the "duty to remember". This duty to remember is a very complex notion. The French philosopher considers it to be "the duty to do justice, through remembrance, to someone other than oneself" [1: 108]. For Belgian historians Bertrams and de Broux, the duty to remember often comes into play several decades after the tragedy happened, when the victims, the executioners and the witnesses already have left the scene [10: 79]. Organisations of victim's descendants then often take over and fight for the remembrance of others, for their ancestors whose memory is at risk of being threatened by oblivion or distortion. It is as if one had to wait until enough time had passed by for the worst of the suffering to be left behind, before daring to look back and seek justice.

The idea of the duty to remember also brings into play the notion of debt, "inseparable from that of inheritance", in as much as it places contemporaries in the position of being indebted for part of what they are to those who preceded them [1: 108].

Memory can travel through generations of people and can sometimes entrap them. When forced to remember, one might fall into a victimological perception of historiography. History risks then no longer to be a tool of emancipation but to become one of alienation, setting victims against their executioners and thereby reducing the inherent complexity of history. The duty to remember comes close to what Friedrich Nietzsche called "antiquarian history", focused to preserve and admire the past, yet without being able to look at the future [11]. Nietzsche warns that "There is always the danger here, that everything ancient will be regarded as equally venerable, and, everything without this respect for antiquity, like a new spirit, rejected as an enemy. (...) If the judgment of a people harden in this way, and history's service to the past life be to undermine a further and higher life; if the historical sense no longer preserve life, but mummify it: then the tree dies, unnaturally, from the top downwards, and at last the roots themselves wither" [12: 311].

Whether one thinks of the victims of wars, colonization or ethnic massacres, the duty to remember is also materialized by heritage representing these tragic events, remnants of a history that one prefers to forget, but which must be remembered so that they will never happen again. For instance, the Auschwitz-Birkenau concentration and extermination camp has been a UNESCO World Heritage Site since 1979 as a place of remembrance and now serves as a witness to the scale of the crime [2]. Poland turned the former site of the camp into a museum as early as 1947 so as not to forget the horrors suffered there. Similarly, Constitutional Hill in South Africa, a former prison during the Apartheid regime, now houses the Constitutional Court 
and is protected as a heritage site of national interest, in part because of the darker heritage which must be remembered [13].

In Belgium, the National Memorial of Breendonk as well as the Kazerne Dossin in Mechelen served as transit camps which were used by the SS during the Second World War [14]. Both places are now listed as monuments and are used for remembrance. The Kazerne Dossin, also a Museum for the Holocaust and Human Rights, was however recently in turmoil because of conflicting views on how to conduct this duty to remember. The director and several board members left the institution and created a new Hannah Arendt Institute for diversity, urbanism and citizenship [15]. Moreover, in the summer of 2020, the Federal Parliament set up a Truth \& Reconciliation Commission for Belgium's colonial past (in Congo, Rwanda and Burundi) [Commission spéciale chargée d'examiner l'état indépendant du Congo (1885-1908) et le passé colonial de la Belgique au Congo (1908-1960), au Rwanda et au Burundi (1919-1962), ses conséquences et les suites qu'il convient d'y réserver, Parliamentary Doc., 17 July 2020, nr. 1462/001]. Even before it started, this new commission has already been controversial $[16,17]$. It stirs a lot of debate among the Belgian public, and especially among historians [18, 19] and activists $[20,21]$, which once again demonstrates how working on memory of a tragic past is complex.

\subsection{The Inherent Subjectivity in Historical and Heritage Research}

In his analysis of history, and more precisely of the epistemology of historical knowledge, Ricoeur differentiates history (which seeks truth) and memory (which looks for loyalty) [1: 168]. Indeed, there is a difference between the historical fact and the actual event remembered, between written history and the memory of witnesses, the reliability of which may be questioned. As far as the historian is concerned, he claims to "represent the past in truth", situating himself as the "critical extension" of the ambition of fidelity of memory, which seeks, for its part, to "make something present that was absent before" [1: 295-296]. What the memory of the witnesses cannot guarantee, the historian can, insofar as history claims to be "the erudite heir to memory" [1: 304].

Like the historian, the heritage professional clearly has a responsibility to the past in so far as they both contribute to its knowledge [1: 336-337]. They must be careful not to destroy or lose these marks of history, which are vital to our human development. In The Ethics of Cultural Heritage, Ireland and Schofield confirm that, during the twentieth century, the ethics of responsibility for cultural heritage was primarily designed to establish conservation standards and professional ethics, which were mainly of Western influence [22]. Heritage responsibility was directed towards the material conservation of property, (duty of conservation with regard to cultural property, monuments, sites, but also archives and archaeological data, backed up by professional codes) to establish the authority of heritage experts, towards the public who had to trust in the capacity of professionals, as well as towards heritage professionals themselves (craftsmen, restorers, architects for conservation, etc.) in order to legitimize their expertise. However, several ethical questions arise in this work 
of heritage conservation or, to take up Ricoeur's field of analysis, of historiographic representation. Ricoeur endeavours to demonstrate that history cannot claim to know the truth about the past. Indeed, if the historian is careful to distance himself from living memory, in order to better understand historical facts, his work of knowledge and distancing is necessarily carried out by means of archival material, which comes from the testimony of men of the past. In other words, before being the object of historical knowledge, an event is first of all the object of narrative (through archives), hence the return of the paradox encountered on the question of memory, namely that of the debate between recollection and imagination and/or between reality and fiction.

Moreover, any historian finds himself in the position of an engaged spectator, and not in that of a neutral agent, as he always remains a social being.

Finally, Ricoeur argues that the historian could not write a univocal history, which would cancel out the differences between points of view [1: 427], nor could he write a global history, which would embrace that of the perpetrators, the victims and the witnesses altogether. This task of the historian seems particularly impossible in the face of extraordinary events, relating to what Ricoeur describes as "unacceptable", such as the events he experienced during the Second World War.

These considerations which relate to the inherent subjectivity in the work of a historian can also be seen in the field of cultural heritage. Smith developed the notion of 'authorized heritage discourse', which according to her "is reliant on the power/ knowledge claims of technical and aesthetic experts, and institutionalized in state cultural agencies and amenity societies", but at the same time undermines "alternative and subaltern ideas about "heritage" [23: 11]. Therefore, the cultural heritage professional should take great care in his or her work of knowing and preserving a place, practice or object, running the risk of transforming them, even unconsciously, in such a way that this act of fixing the past may have negative effects for those whose culture would have been appropriated in this way [24].

\subsection{The Sometimes Salutary Oblivion of Heritage}

Finally, in his research on oblivion, the sometimes negative and agonising phase of memory, Ricoeur also detects its legitimate and salutary function, not in the form of an injunction, but in that of a vow. In other words, he observes that "there would be a measure in the use of human memory" and that "forgetfulness would not therefore be in all respects the enemy of memory, and memory would have to negotiate with forgetfulness to find the right measure of its balance with it" [1: 537]. A memory that forgets nothing would be "monstrous" in a way [1: 537].

Similarly, cultural heritage is struggling against a negative form of oblivion, understood as the "erasing of traces" [1: 543]. But a more positive form of oblivion is nevertheless necessary. It is neither possible nor desirable to protect everything, to freeze the past so as not to forget anything, thus not leaving any room for the present or the future. Heritage must also be lived, be part of the life of the community, stay in the dynamic and not be frozen until it loses its value due to a lack of interest. 
Conservation through transformation is a subtle but welcome balancing act to maintain flexibility in heritage policies.

According to this dynamic logic, some properties may lose their symbolic value and no longer be of cultural interest to the community, whose gaze turns away, while the buildings gather dust. The emptying of the faithful from many churches and chapels raises the question of their protection on such a large scale: does it still make sense? More and more initiatives are being taken for the reuse, or even reassignment, of certain churches, but as Chastel and Babelon point out, the scale of the legacy is frightening [25: 101]. For both historians, "we create great difficulties for ourselves", "through our attachment to our heritage" [25: 101]. They recall that "in every society, heritage is recognized by the fact that its loss constitutes a sacrifice and that its preservation presupposes sacrifice", which is the hallmark of all sacredness [25: 101]. This problematic echoes Hannah Arendt's reading of the inherent beauty of any object or cultural good, beyond its use or function, which makes it "last through the centuries" even specifying this for cathedrals, "while they as buildings certainly served the needs of the community, their elaborate beauty can never be explained by these needs, which could have been served quite as well by any nondescript building" [26: 204]. Even if her conception of art and culture (strongly centred on beauty and Kant's "disinterested joy") differs from the current evolution of the notion of heritage precisely (see 2.1.), her statement on cathedrals shows how difficult it would be to decide to sacrifice and stop protecting empty churches. Delisting certain monuments or sites is a necessary part of a thriving heritage policy, but it should always follow a thorough case-by-case analysis in order to ascertain the loss of cultural interest. In other words, a policy of the "right memory", or of the right patrimonialisation (i.e. the process of what being protected as heritage), balanced between preserving and forgetting the past, should therefore guide the responsible work of different heritage actors.

The above analysed complex relationship between heritage, history and memory is somehow reflected in heritage regulation, as will be analysed in the second part. Still the questions remain: how is the need to protect and remember our past in order to shape our future translated into legal measures? How does the law attempt, or fails to attempt, to limit potential abuses of heritage and memory? How can regulation temper the absence of neutrality of heritage protection?

\section{What Heritage to Be Remembered According to Belgian Law}

The second part of this paper analyses Belgian cultural heritage law in order to understand how regulation evolves with social and ethical considerations regarding the past. Heritage protection is closely linked to what one seeks to remember, and might therefore shift over time and space.

First, the enlargement of the legal scope, from monument to cultural heritage ('patrimoine culturel'), gives a broader view on what should be preserved and consequently remembered from the past. If the term cultural heritage has only gradually appeared, it goes without saying that this appearance goes hand in hand with a broadening of the notion of monument itself. The former does not replace the 
latter however; the notion of cultural heritage rather opens the doors to an extended dimension, beyond the enlarged notion of monument.

Second, the participation measures enshrined in cultural heritage legislation could be an interesting indicator of how heritage, if socially constructed, should be co-determined. However, in reality the State still holds the power to decide what is worthy of heritage protection, which in turn entails certain risks of forgetting, abandoning or even destroying heritage.

Finally, the international and constitutional recognition of a human right to cultural heritage is in line with the ethical and social paradigm shift operating in cultural heritage. Such a human right recognizes individual and collective access to heritage, although its enforceability remains weak.

\subsection{The Extended Legal Scope: From National Monument to Regional Heritage}

For a long time, the first legislations in Belgium and elsewhere used the term "monument", "site" or "cultural object" to designate objects and properties worthy of protection because of their cultural, artistic or historical interest.

The French architectural and urban historian Françoise Chaoy places the origin of the concept of "monument" at the French Revolution, having a national (and no longer monarchical or religious) concern to preserve the traces of the past and the ancient regime [27]. However, some authors, such as the art historian Jean-Michel Leniaud, do not share this analysis. Leniaud believes that by asking ourselves three defined questions (what deserves to be preserved? what are the motivations for accepting or rejecting the past? according to what modalities has heritage been preserved and transmitted?), "we will recognize the presence of fragments of heritage consciousness in societies largely preceding ours" [28] and going much earlier than the French Revolution.

The Belgian law of 7 August 1931 on the conservation of monuments and sites [Loi du 7 août 1931 sur la conservation des monuments et des sites, Moniteur belge, 5 September 1931], protected prestigious monuments (cathedrals, palaces, exceptional works of art) of considerable cultural interest. The administrative practice prior to the adoption of the 1931 law already classified monuments into three categories according to their cultural importance. The vision was therefore strongly pyramidal and was limited to what were considered to be grandiose architectural achievements when dated back at least a century. There was no question of recognising the same cultural value to younger buildings, as historical distance was necessary to determine the value of the property seriously and objectively. Going back to the Quattrocento in Italy, Choay explains that the princes, popes and other protectors were already obsessed with antiquity: "Taking distance from the buildings of the past requires a long apprenticeship, in a period of time that knowledge cannot be contracted and that is necessary for respect to replace familiarity" [27: 47].

A similar elitist reasoning was followed for movable cultural property: only the nation's true treasures would be protected [Law of 7 August 1931 and Loi du 16 mai 1960 relative au Patrimoine culturel mobilier de la Nation, Moniteur belge, 5 August 1960, although the latter law never entered into force]. 
A few decades later, and partly under the influence of the Council of Europe's conventions, Belgian legislation extended its conception of the properties to be protected and moved from the notion of "monument" to that of "heritage" in its public policies.

Indeed, as difficult as it is to determine when a certain concept or notion is used and how it is understood by a society at a given time, it becomes easier when looking at their introduction in legal texts. For André Desvallées, Honorary General Curator of Heritage in France, the term of heritage, as it is currently understood-for it is in fact much older - only appeared in French national texts from the 1960s and 1970s, as it did with Belgian law. The notion had already been mentioned in international circles by the IOM in 1931 [29: 12] (International Museums Office, the forerunner of ICOM) and by UNESCO in 1945; it had also emerged in other national laws (German, Italian, Portuguese, Spanish, etc.) [30]. Moreover, the concept of heritage has been widely used since the end of the 1980s, under the impetus of the European Heritage Days, also organised at a national level by the three regions in Belgium since 1989.

Desvallées emphasizes the importance of this evolution. The current meaning of the term heritage is important to understand because "if the thing was essential, the word was also important", as "the choice one makes of one word in preference to another can lead to nuances - and changes - in the meaning of the thing" [29: 7].

He further explains the difficulty of translation between the French word of patrimoine and its English counterpart [30: 14-15]. This was also highlighted by Frigo concerning the influence of domestic legal traditions when elaborating international conventions: cultural heritage and patrimoine culturel do not exactly convey the same legal traditions, although the concepts are quite similar [31]. At first, during the 1931 session of IOM, patrimoine was translated by 'property' in the English summaries of the Conference of Athens. This shows the importance the concept of 'cultural property' had, before being replaced by 'cultural heritage', which, as Patrick O' Keefe and Lyndell Prott confirm, has a broader scope [32]. The UNESCO Constitution of 1945 understood the French 'patrimoine universel' as the English 'world's inheritance' [Article I] and in the 1950s the use of 'world's cultural heritage' or 'cultural heritage of mankind' and then 'cultural heritage' seem to grasp the French notion of "patrimoine culturel (de l'humanité)". However, Desvallées observes a similar restraint during the 1950s and 1960s in France and Great Britain to use these terms of cultural heritage and patrimoine culturel, as the other onesmonuments, cultural property or archaeology—were still widely used until the 1970s.

Cassin and Wozny noted, however, that while the shift towards using the term cultural heritage is shared in Europe, it is not always followed elsewhere because the words museum and heritage, and the concepts to which they refer, are among the great untranslatable words in European languages [33]. Similarly, Babelon and Chastel denounce the obvious artifice behind the fact that Third World countries should designate their heritage following categories of Western countries (like monuments, groups of buildings and sites), even though their own traditions and customs do not imply such monumental symbols [25: 105]. 
In Belgian legal language, the word heritage is however ambiguous, revealing its symbolic nature: that of "a duplicated reality, a given and a constructed (given heritage and meaning to be constructed) whose vocation is to be transmitted" [34]. It oscillates between individualism and collectivism, depending on whether it is perceived under private or public law.

In civil law, patrimoine or heritage designates all goods, present and future, tangible and intangible, attached to a person and forming a universality of rights, which is measurable in money. Taking up this definition, article 3.35 of the new Civil Code specifies that: "Le patrimoine d'une personne est l'universalité de droit comprenant l'ensemble de ses biens et obligations, présents et à venir. Toute personne physique ou morale a un et, sauf si la loi en dispose autrement, un seul patrimoine." [Loi du 4 février 2020 portant le livre 3 'les biens' du Code civil, Moniteur belge, 17 mars 2020, entry into force on 1 September 2021] This meaning goes back to Roman law and the idea of inheritance, which is intrinsically linked to that of heritage.

In contrast to this approach, a collectivist perception of heritage emerged in Belgian public law, based on the idea of conservation and transmission, where goods have a symbolic value, which is that of cultural interest.

According to this second meaning, the notion of heritage or 'cultural heritage' inevitably refers vaguely to all the "treasures" of the past" [34: 11]. Broader than the concept of monuments, the concept of cultural heritage encompasses not only monuments, sites and protected areas, but also archaeology, cultural property, intangible heritage, maritime and underwater heritage, industrial heritage and landscapes. Currently, the concept of cultural heritage applies to a wide variety of sectors, to the point where everything can become heritage [29: 23].

In the Comparative Dictionary of Cultural Heritage Law, a synthetic definition of cultural heritage can be found in its broadest sense, based on the various legal definitions of several European countries as "all traces of human activities, tangible or intangible, which are of value to a given community and whose safeguarding and protection must therefore be ensured" [35: 740]. The Council of Europe Framework Convention on the Value of Cultural Heritage for Society (2005) equally gives a broad definition for cultural heritage, understood as "a group of resources inherited from the past which people identify, independently of ownership, as a reflection and expression of their constantly evolving values, beliefs, knowledge and traditions. It includes all aspects of the environment resulting from the interaction between people and places through time" [Article 2, a].

The transition from the notion of monument to that of heritage is not insignificant and it thus reflects a new vision, in phase with a deeper paradigm shift: heritage is no longer only valued because of its mere existence, but it is also worthy of protection because of its use by people having a right to access it. Legally speaking, cultural heritage law is not only about the law of the protected thing, but also about the right of the people to their heritage (see 2.3.).

This evolution mirrors that of the Belgian State, moving from a unitarian NationState to a decentralized Federal State in 1970. The federalization could be seen as the first recognition of diverse cultural identities protecting their own heritage.

Three communities were created in 1970 (the Flemish, French and Germanspeaking Communities) and then three regions were created in 1980 and 1988 (the 
Flemish and Walloon, and then the Brussels-Capital Regions). The creation of the communities (first called 'cultural communities' before being renamed as 'communities') shows the importance of the cultural dimension and therefore the cultural identity of such a political entity [36]. Heritage protection has also been at the core of the communities' policies. The first legislation the brand-new Flemish Community adopted in 1972 was to amend the law of 1931 concerning monuments and sites. From then on, cultural heritage became a community-based competence and several autonomous legislations were adopted by the three communities, also broadening the scope of protected elements, encompassing a wide variety of cultural heritage fields.

In 1988 however, the competence was quite artificially split between immovable heritage (monuments, sites, archaeology, landscape), which was transferred to the three regions (Brussels-Capital, Flanders and Wallonia) and the German-speaking Community; while movable (cultural goods) and intangible heritage remained with the three communities (Flemish, French and German-speaking) and a part of movable and intangible heritage was transferred in 2014 to the Brussels Region [36]. Furthermore, the Federal State still remains competent for the ratification of international conventions and for a few national museums and cultural institutions. The federated states (both regions and communities) also have international competence for the areas falling within their powers.

As a result, not less than seven different lawmakers are competent for cultural heritage regulation in the actual Belgian legal landscape, adopting legal measures for different aspects of cultural heritage and elaborating their own legal scope, protective regime and administrative instruments [37]. In other words, no legislation offers an overarching definition of cultural heritage, as none of the federal states is entirely competent in their own territory, except the German-speaking community (who still have a split legislation).

Belgian law does therefore not contain a legal definition of cultural heritage at federal level. At the level of the federated entities, several legal definitions are drawn, each according to the specific and exclusive competence of the federated entity in question.

A brief overview of tangible cultural heritage legislation already shows some varieties between what one legally considers worthy of protection and according to which criteria.

Concerning immovable heritage, the Walloon Heritage Code offers an interesting definition in its Article 1, citing a long list of interests to justify protection and including the notions of rarity, authenticity, integrity or representativeness:

Le patrimoine comprend l'ensemble des biens immobiliers qui constituent un reflet et une expression des valeurs, croyances, savoirs, savoir-faire et traditions en continuelle évolution, dont la protection se justifie en raison de leur intérêt notamment archéologique, historique, architectural, scientifique, artistique, social, mémoriel, esthétique, technique, paysager ou urbanistique et en tenant compte de critères de rareté, d'authenticité, d'intégrité ou de représentativité. Cela inclut tous les aspects de l'environnement résultant de l'interaction dans le temps entre les personnes et les lieux (freely trans- 
lated: "Heritage includes all immovable property which is a reflection and expression of values, beliefs, knowledge, know-how and traditions in constant evolution, whose protection is justified because of their interest, particularly archaeological, historical, architectural, scientific, artistic, social, memorable, aesthetic, technical, landscape or urbanistic interest, and taking into account criteria of rarity, authenticity, integrity or representativeness. This includes all aspects of the environment resulting from the interaction over time between people and places").

The Brussels Urban Planning Code specifies that the immovable heritage includes "l'ensemble des biens immeubles qui présentent un intérêt historique, archéologique, artistique, esthétique, scientifique, social, technique ou folklorique" (freely translated: "all immovable property of historical, archaeological, artistic, aesthetic, scientific, social, technical or folklore interest"). The Code then lists the four components of immovable heritage in the same article 206, being the monument, ensemble, site and archaeological site. Here also, some interests are listed, albeit less than in Wallonia and no mention is made of specific requirements relating to rarity, authenticity, integrity or representativeness.

The Flemish decree of 12 July 2013 on immovable heritage [Decreet van 12 juli 2013 betreffende het Vlaams Onroerend Erfgoed, Moniteur belge, 17 October 2013] is intended to be even more functional, defining immovable heritage as "all archaeological sites, monuments, historical-cultural landscapes and urban and rural sites" (article $2.1 .39^{\circ}$, freely translated). The criteria to select what should be protected are however specified in article $2.1 .26^{\circ}$ and are quite similar, albeit slightly different, from its Walloon and Brussels counterpart:

$26^{\circ}$ heritage value: the archaeological, architectural, artistic, cultural, aesthetic, historical, industrial-archaeological, technical, spatial-structural, social, urban planning, folkloric or scientific value from which immovable property and the cultural goods that form an integral part of it derive their present or future social significance (freely translated).

Concerning these criteria, Vandenhende defends that the existing legislation should entail more binding criteria in order to have a more efficient and predictable heritage policy [38].

The decree of the German-speaking Community of 23 June 2008 on heritage (Denkmalschutzdekret) finally limits itself to defining the elements without offering a definition of the whole (monument, ensemble and site), but each time lists the "archaeological, aesthetic, historical, artistic, cultural, folklore, scientific, social or technical value" attached to such a monument, ensemble or site in order to be protected (article $1,1^{\circ}, 2^{\circ}$ and $3^{\circ}$, freely translated).

The Walloon, Brussels and German-speaking legislators also include small (popular) heritage ("petit patrimoine (populaire)"), understood as those elements that are not listed, but which have a mainly local heritage interest, whilst being visible and/or accessible to the public. The Walloon legislator, unlike the other legislators, finally gives a specific place to world heritage, referring to the 1972 
Convention for the Protection of the World Cultural and Natural Heritage, while linking certain specific protection measures to it.

With regard to movable cultural heritage, the various pieces of legislation again do not provide a general definition of cultural heritage nor to movable cultural heritage. They mostly refer to the categories found in Regulation (EC) No. $116 / 2009$, but they all provide a specific definition for protected cultural goods (i.e. masterpieces, treasures, particularly remarkable cultural objects).

For the Flemish Community, Article 2, $10^{\circ}$ of the Decree of 24 January 2003 on the protection of the movable cultural heritage of exceptional interest [Moniteur belge, 14 March 2003] defines a masterpiece ('topstuk') as "a movable item referred to or a collection referred to in Article 2bis, whether the movable item is included or the collection is included in the list or not" (freely translated).

Furthermore, under Article 2bis:

A movable asset or collection is considered to be a masterpiece when, because of its archaeological, historical, cultural-historical, artistic or scientific importance for the Flemish Community, it must be considered rare and indispensable.

In the first paragraph:

$1^{\circ}$ rare: a piece of furniture or a collection of which few copies - identical or similar - are present in the same condition within the Flemish Community; $2^{\circ}$ indispensable: a movable property, or a collection, which has at least one or more of the following characteristics:

- a special value for collective memory, by which is meant the function of remembering marked, among others, persons, institutions, events or traditions that are important for the culture, history or practice of science in Flanders;

- a link function, which is understood to mean the function of a relevant link in a development that is important for the evolution of art, cultural history, archaeology, history or the practice of science;

- a benchmark value, by which is meant the function of an important contribution to the study or knowledge of other important objects of art, culture, archaeology, history or science;

- a particular artistic value, by which is meant artistic significance in relation to known artistic production] (freely translated).

The French Community defines treasures in Article $1, \S 1, \mathrm{~b})$ of the Decree of 11 July 2002 relating to movable cultural property and the intangible heritage of the French Community [Décret du 11 juillet 2002 relatif aux biens culturels mobiliers et au patrimoine immatériel de la Communauté française, Moniteur belge, 24 September 2002] as:

(b) Trésors

1. Les biens culturels mobiliers repris dans la liste en annexe du présent décret, ayant une valeur égale ou supérieure aux seuils financiers repris 
dans la même annexe et qui sont classés comme des trésors conformément aux dispositions de l'article 4 du présent décret;

2. Les objets faisant partie des inventaires des institutions ecclésiastiques et qui sont classés comme trésors conformément aux dispositions de l'article 4 du présent décret;

3. Les objets faisant partie des collections des pouvoirs publics qui sont établis dans la région de langue française ainsi que ceux qui sont établis dans la région bilingue de Bruxelles- Capitale et qui, en raison de leur activité, doivent être considérés comme appartenant exclusivement à la Communauté française et qui sont classés comme trésors conformément aux dispositions de l'article 4 du présent décret.

(freely translated:

(b) Treasures:

1. Movable cultural property included in the list in the appendix to the present decree, having a value equal to or greater than the financial thresholds set out in the same appendix and which are classified as treasures in accordance with the provisions of article 4 of the present decree;

2. Objects forming part of the inventories of ecclesiastical institutions and which are classified as treasures in accordance with the provisions of article 4 of the present decree;

3. Objects forming part of the collections of the public authorities which are established in the French-speaking region as well as those established in the bilingual region of Brussels-Capital and which, because of their activity, must be considered as belonging exclusively to the French Community and which are classified as treasures in accordance with the provisions of article 4 of the present decree.

The German-speaking Community talks of particularly remarkable cultural objects in Article 2, 1 of the Decree of 20 February 2017 on the protection of particularly remarkable movable cultural property [Dekret zum Schutz des beweglichen Kulturgutes von Ausserordentlicher Bedeutung, Moniteur belge, 7 April 2017] "a movable cultural property included in the inventory of valuable movable cultural property of the German-speaking Community because of its diverse artistic, historical, archaeological, scientific or cultural value" (freely translated).

Finally, the Brussels-Capital Region gives the following definition of a treasure in Article $5,3^{\circ}$ of the Ordinance of 25 April 2019 relating to the movable and intangible cultural heritage of the Brussels-Capital Region [Ordonnance du 25 avril 2019 relative au patrimoine culturel mobilier et immatériel de la Région de BruxellesCapitale, Moniteur belge, 17 May 2019] " $3^{\circ}$ trésor: un bien culturel classé par la Région conformément aux dispositions de la Sect. 5 (articles 11 et suivants)" (freely translated: " $3^{\circ}$ treasure: a cultural asset classified by the Region in accordance with the provisions of Sect. 5 (articles 11 and following)").

The notion of 'national treasure' from the European texts on the subject (Article 36 TFEU and EU Directive 2014/60) is only literally included in the federal law transposing the directive [Loi du 28 octobre 1996 relative à la restitution de biens culturels ayant quitté illicitement le territoire de certains Etats étrangers, 
Moniteur belge, 21 December 1996]. In the other legislations, either the term 'national' disappears to keep only the concept of 'treasure' (in the French Community and the Brussels-Capital Region), or the term 'treasure' and a fortiori 'national' is replaced by a similar concept: 'masterpiece' in the Flemish Community and 'particularly remarkable movable cultural object' in the German-speaking Community.

The disappearance of the notion of national should not be surprising, insofar as the competence to protect movable cultural property does not lie with the federal State, the only one that can claim national application of its legislation, but with the federated entities (in this case, the three communities and the Brussels-Capital Region) which act within the limits of their territorial competence. The French Community justified its own choice not to use the term national, which seemed "inappropriate" to the drafters of the decree because of the community-based competence for cultural matters [Explanatory Memorandum to the 2002 Decree, Parl. Doc., Comm. fr. sess. ord. 2001-2002, 15 May 2002, No. 271/1, p. 6].

As can been noticed from the various definitions above, the concept of tangible cultural heritage also broadened over the last decades, besides the diversification of the several cultural heritage fields. The work of sociologist Nathalie Heinich is very interesting in that respect. She recognized four types of extension that apply to what, in France, are called "historic monuments", and which in Belgium are called "monuments and sites" and "cultural objects", both tangible cultural heritage [39: 17-21].

Firstly, the chronological extension implies that historical distance is becoming less and less a criterion for heritage recognition, opening up more to properties of the present. For instance, the Post Office building in Ostend was protected 28 years after its construction in 1953,[40] the villa Le Pangolin built by the Belgian architect André Jacqmain in 1966-1968 was listed in 2004, 44 years after its construction,[41] and the Rozenberg Abbey built in Waasmunster in 1972-1975 was protected 34 years later by the decision of 5 October 2009 [42]. For Heinich, we see with this evolution the appearance of a "heritage precautionary principle" (avoid forgetting to protect an element of the existing world, which could go so far as to mean protecting everything), in direct opposition to the old "aesthetic precautionary principle", which invites us to distance ourselves from it in order to appreciate its beauty [39: 18].

The second extension is topographical, including sites, protected areas, historic towns and landscapes in heritage protection. One no longer looks at the place in isolation, but in its environment. The concept of integrated conservation was also introduced in the law around the 1980s.

The extension of the categories constitutes the third opening of the notion of monument toward heritage. It is no longer just a question of protecting prestigious monuments, whose aesthetic canons are indisputable, but also unique properties or, conversely, properties that bear witness to "traditional daily life, transport, trade and industry: farms and farm buildings, fountains, wash houses, wayside crosses, mills, ovens, rural craft tools, or even halls, cafés, cinemas or theatres, shop decorations, street furniture, signs, or even stations, mines or factories" [39: 18-19]. From the 1970s and 1980s, the various Belgian legislations began to add scientific, technical, folkloric, popular, etc. interests to the definition of a monument. 
Finally, the concept of heritage itself has been extended from the "logic of unicum", which values the unique, rare, exceptional piece, to that of "typicum", which is concerned with the context, the whole, the element of a series [39: 20].

The rationale of the unicum is still largely favoured for movable heritage as one can see from the notion of 'topstuk', a masterpiece, in Flanders, and that of 'treasure' in the French Community and Brussels Region. For some listed immovable heritage, the idea of rarity and uniqueness is equally preferred, following the same reasoning.

Yet, the typicum approach is followed for other protected buildings or sites or for intangible heritage. The second approach is also interesting for heritage registered in the inventory or on a provisional safeguard list. Sometimes items are listed in the inventory, not for their rarity, but for their typicality, such as certain façades of manor houses in Brussels or scientific collections in a university library.

\subsection{Who Participates in Determining What is Heritage?}

This increasingly wide extension of the legal scope nevertheless leaves one wondering: what is heritage? Even though selection criteria are drawn by most lawmakers, thereby circumscribing what is considered to be heritage according to the law, it nonetheless follows the idea that anything could be heritage as long as it is recognised as such by the community.

Heritage would then be a social construction: what matters is not an a priori ontological definition of heritage, but rather the process of patrimonialisation, which is what the "idea of cultural heritage" is all about [25: 13]. As Smith wrote: "There is, really, no such thing as heritage" [23: 11]. A definition exercise would anyway be a difficult undertaking, given the elusiveness of the notion of culture itself; it would be more a question of identifying elements of cultural heritage rather than defining them. Bories acknowledges that "The law thus relies on fact and on other human sciences to apprehend cultural heritage and identify its different components" [43: 60].

The contribution of sociologists is valuable in that they have made it possible to bring to light the real issue at stake in the debate: "it is not a question of knowing what is heritage, but of determining who decides what becomes of it" [44: 19]. The law therefore plays its role by enacting the rules of procedure necessary to frame public action, translating the question "what is heritage" into "how should heritage objects be selected and protected?" [39: 30]. Yet heritage regulation shows the discrepancy between the ambition to socially construct heritage, by recognising its social importance among the community, and the actual legal measures to include these stakeholders, still keeping the power to determine what is heritage in the hands of the State and its administration. Participation measures have indeed been adopted over the years and paved the way for a more inclusive heritage governance (2.2.1.), but the public authority still has the monopoly to decide what cultural heritage to protect (2.2.2). 


\subsubsection{Participation in Belgian Cultural Heritage Law}

Collective participation may be measured through several missions of heritage protection: identification, description, interpretation, promotion and management of cultural heritage.

Concerning the identification of cultural heritage, the public participates through its right of initiative, a more "proactive" than "reactive" power [45: 47], sometimes even approaching the role of a whistle-blower. This right is not officially recognised in every legislation. For immovable heritage, Walloon and Brussels citizens have, under certain terms and conditions, the right to initiate a request for protection of immovable cultural heritage, unlike Flemish (with nuances in practice) and Germanspeaking citizens. For movable cultural heritage, the French Community provides for a right of initiative in favour of the community under certain conditions (500 signatories domiciled in the French-speaking region or in the bilingual region of Brussels-Capital), in contrast to the Flemish and German-speaking Community, which do not provide for such a right of initiative for the public. However, the competent authority still holds its discretionary power to undertake protection proceedings, no matter who initiated it (public or local authority, owner, citizen...).

Furthermore, the public enquiry is a participatory modality widely used by public authorities and is included in all legislation relating to immovable cultural heritage, but not to movable cultural heritage (only the owner's observations are provided for) and takes place during the identification/protection process. This difference is probably partly due to the split between both movable and immovable heritage and the proximity of immovable heritage to the fields of urban planning and the environment, where the use of public enquiry is widespread. The public enquiry is limited to decisions to protect (or not) the property concerned, and not to subsequent administrative decisions. However, the holding of a public enquiry does not bind the competent authority, except that it must give reasons for its decision in the light of remarks that are made at the enquiry [46].

With regard to the description of cultural heritage, as well as its interpretation, the advisory commissions composed of experts and sometimes members of the civil society play an important role. For immovable cultural heritage, the Royal Commissions for Monuments and Sites of the Walloon and Brussels regions and the German-speaking Community (the Walloon CRMSF, the Brussels CRMS and the German-speaking CRMS) and the Flemish Commission for Immovable Heritage (the Vlaamse Commissie voor Onroerend Erfgoed, VIOE), composed mainly of experts and representatives of civil society (explicitly mentioned for the Brussels CRMS (associations) and the VIOE (civil society)), have proved to be four valuable bodies in the protection decision. With regard to movable heritage, there is the Council for the Conservation of Movable Cultural Heritage in the Flemish Community, but which in practice includes private collectors, and the Consultative Commission for Cultural Heritage in the French Community (composed exclusively of experts and representatives of the administration but without voting rights), although to date none exists for the German-speaking Community. Brussels has a specific movable and intangible heritage department within its CRMS. 
Most of these consultative commissions only give opinions-although they are sometimes binding, such as in Brussels-on requests concerning cultural heritage properties. The commissions may also make recommendations for heritage policy, thereby participating in the description and interpretation of cultural heritage. Nevertheless, the recommendations made by these participatory commissions are not binding on the public authorities, who do not have to take them into account, even if they do try to do so in practice. These commissions have nonetheless the advantage of a certain permanence and stability in the participatory process, as well as expertise in the subject matter.

The promotion of heritage increasingly includes citizens and the entire heritage community, as evidenced by the recent themes of the Heritage Days (the theme in Brussels for the 2018 edition was "Heritage is us"). In addition, citizen organisations sometimes act as intermediaries with the general public to promote access to and the enjoyment of heritage, obtaining subsidies for this purpose from the public authorities.

Finally, heritage management can include different stakeholders, but on a caseby-case basis and not generally through legislation. For example, heritage protection associations can help to participate in the management of heritage, without holding property or any other real rights.

Despite this variety of participation, collective groups linked to cultural heritage, often organised in associations, suffer from a lack of recognition for their actions and are short of resources. The risk is that these heritage defence groups will bear a heavy responsibility, as they do not always have the human, the technical or the financial resources to ensure that heritage is or remains protected. Other difficulties may arise while combining participation, protection and management roles, or as to the identity and legitimacy of certain heritage protection organisations, as Ost already noted a long time ago for environmental associations [47].

Although some participative measures are enshrined in cultural heritage legislation, these are only first forays, and do not yet provide the basis for a strong and integrated participation in heritage policy. In addition, as Delnoy and a number of other Belgian lawyers note, there is no general principle of participation, from which the rights provided for in the legislation would derive [46]. It is up to each lawmaker to establish the scope of participation in the areas of their choice: the material scope (the areas in which the public can participate); the personal scope (the people invited to participate are often fixed, such as the inhabitants around the monument, or the citizens gathered in non-profit organisations, experts for consultative commissions, etc.); and the territorial scope (a specific territory, a certain perimeter around the monument or site).

Nevertheless, bottom-up initiatives have gradually multiplied throughout Europe, as noted in the Participatoy Govenance in Cultual Heritage report of 2018 [48], making it possible to observe which incentives encourage the use of the participatory approach to protect cultural heritage, and also which obstacles hinder it. Moreover, the observation of practical cases reveals a positive impact of participatory governance methods for heritage, encouraging public authorities and all other actors to continue along this path. 
The public is thus increasingly seen as an active player in the protection of cultural heritage insofar as it is included in the process. Whilst reports such as the European Union's [48], as well as studies in other disciplinary fields [49], show that things are moving in practice, the possibilities for the public to act at the court level are still in their infancy [50].

\subsection{Risks Attached to a State Monopoly on Heritage Regulation and Protection}

Despite some legally recognised degree of participation, deciding on what heritage to protect remains a State [understood as the competent public authority in Belgium's federal State structure] prerogative, which is quite understandable as it exercises sovereign power, but nevertheless requires critical analysis.

For Wagener, the extension of cultural heritage protection would reveal "the continuous growth of the legal powers of the State" [51: 112]. According to him, "the history of the legal protection of cultural heritage merges, first and foremost, with that of the gradual conquest of the State's monopoly on decision-making related to cultural heritage" [51: 112]. Confirming this critical evaluation of the State's powers, Cornu and Wagener consider cultural heritage as a legal and property struggle: the State has the power to decide the fate of things, even of those it does not own [52]. By regulating the legal scope and adopting a wide array of unilateral instruments (listing, inventorying, ...), the State establishes a strong administrative police.

However, the growing State monopoly entails certain risks, as the State may not always act in the general cultural interest, which in turn questions the legitimacy of such a monopoly. Three types of risks can be noted: the risk of forgetting, of abandoning or of destroying heritage. Some of these risks come close to forms of abused memory highlighted by Ricoeur [1].

First, the risk of forgetting heritage may be unconscious, for instance when heritage is not yet appreciated at the time it was created, such as industrial heritage, or even the Art Nouveau architecture, that were at first disregarded [53].

But heritage may also consciously be forgotten, when the State refuses to protect heritage which does not fit with its political, ideological or religious vision. As a result, certain heritages may be of importance to a particular community, but will not be protected, either because the State decides to neglect that community (cultural or religious minority groups with their own traditions and customs) or because it simply refuses to formally recognise their specific cultural identity (e.g. mosques for Serbian Muslims, mausoleums for Kurds in Turkey or cemeteries for Polish Jews). Potential conflicts may then arise between the State and a particular community, which is often a minority defending a collective interest through the recognition of their cultural heritage. By refusing to protect that heritage, the State exercises its power in a problematic way. It also shows how heritage can be a political struggle and is far from being a consensual conservation act [54: 3].

Conversely, the State may choose to focus on certain heritage elements in order to strengthen its power, and actively manipulate a national memory and identity. This happened during the $19^{\text {th }}$ century, in the age of nation-states, where cultural heritage was one of the best ways of strengthening a national identity. Heritage tells 
an identity story and touches the collective imagination. Choay recognises the role the revolutionary French State played as instigator of the French national identity, desired by an elite [27: 73-92, esp. 88]. During the first century of the Belgian State (1830-1930), cultural heritage was in fact a powerful tool for affirming, or even strengthening, the power of the nation-state [55]. The protection of heritage was be legitimised by a sense of national belonging. Several authors, such as Gellner [56] and Hobsbawn [57], link the nationalism of this period to a phenomenon of cultural uniformization to force an elitist and bourgeois perspective on culture.

Similarly, at the international level, heritage has long been considered in a universal, cosmopolitan and elitist way, in contrast to the anthropological approach, which considers cultural heritage as a way of life resulting from the traditions shared by a human group and which can constitute the basis of a cultural identity. Tangible heritage has, moreover, long prevailed over intangible heritage. Indeed, UNESCO is historically focused on the material object, based on a conception of heritage inherited from European civilizations [58]. For a long time, the protection of monuments, sites and other tangible representations of heritage was given priority, with only a secondary and indirect place for intangible heritage. The 1972 Convention for the Protection of World Cultural and Natural Heritage was primarily concerned with preserving the material aspect of the heritage and ensured the protection of works of 'outstanding universal value', allowing for the worldwide dissemination of the concept of heritage. As Blake notes the intangible aspect has only recently been taken into account in the Operational Guidelines, and only to a very limited extent [59]. In reality, the principle of universality and exceptionality of World Heritage has mainly benefited Western countries, rich in built heritage and urban sites. The distribution of listed properties still today bears witness to the original imbalances. While other forms of heritage (such as natural sites or cultural landscapes) have gradually been recognised, what is covered by the 1972 Convention is limited compared to the variety of heritage approaches at the global level.

Reactions from non-Western countries were not long in coming and, as early as the 1970s, the first applications for protection of non-material heritage were made, following the El condor pasa affair in 1970 [60: 75-77]. The political oppositions between the countries of the North and the South were barely hidden, but there was also a real heritage void to be filled. It was not until the 2003 Convention for the Safeguarding of the Intangible Cultural Heritage that this aspect received international attention. The crisis of authenticity, denouncing the primacy of Western values of art and beauty over the ideas of other civilizations, has also highlighted this underrepresented heritage of minorities or other citizens. A recent EU project is working on this aspect of the valorisation of cultural heritage (2018-2021): "PUnCH: Participation of UNderrepresented citizens for the valorization of the Cultural Heritage" [61].

If the first risk is to forget heritage, the second risk is to leave part of the cultural heritage abandoned, sometimes for budgetary reasons. Generally speaking, the Belgian public authorities remain committed to protecting the heritage of their territory. Nonetheless, protecting cultural heritage entails non-negligible costs. Budgetary imperatives can be used to justify a reduction in public commitment to protected or to be protected heritage. The authorities sometimes diminish the amount of 
subsidies, either generally, as in the Flemish decree of 12 July 2013 compared to the previous Flemish decree, or specifically, such as granting subsidies for a protected property below the maximum threshold set by law.

Furthermore, the public authority may refuse to protect a property, choosing to consign part of the heritage to oblivion, which also raises several questions. In principle, the refusal must be based on heritage reasons (i.e. the property does not have a sufficient cultural interest, which is already complex to assess), but sometimes the authority may hide behind budgetary considerations in order not to take protective measures. It does not always shy away from the economic argument, considering that this reason is sufficient to oppose citizen requests for protection. In fact, the Belgian highest administrative court, the Council of State, has already admitted that budgetary reasons can prevent the protection of a property:

the considerations relating to the possibility of developing an economic activity - which is conceivable even in outdoor sports or leisure areas - with a view also to preserving the immovable heritage are not irrelevant; [considering] that, in the event of classification, which is a more restrictive protection regime than inclusion on the safeguard list, the whole park would risk, in the absence of sufficient financial means, falling into neglect and losing its heritage interest;

Considering that the reasons given for preferring protection through the safeguard list to classification are not inadequate (freely translated) [Council of State, arrest nr 237.862, 30 March 2017, a.s.b.l. Bruxelles-nature]

The financial argument in this case overrides other legitimate grounds for public action to protect heritage. The shift signals a disempowerment of the State, which uses the budgetary criterion to abandon its protective role.

This evolution, which is most notable for immovable heritage, is maybe in a way understandable: the regions have protected an increasing number of properties (especially in the 2000s in Wallonia and already earlier in Flanders), and budgets have not necessarily followed through. Movable heritage is also confronted with financial reasoning, especially in the Flemish and German-speaking Community where the refusal to grant an export license for a listed property means that it has to be bought back by the Flemish Government at the international market price.

Third and finally, the State can not only forget, deny or abandon heritage, but at a more radical level it can also destroy it, by action or omission. Heritage may be destroyed for lack of State measures that give precedence to cultural interests over other interests, particularly economic or town-planning interests. In a way, the State, by omission, lets heritage go when other issues are at stake, erasing traces of this past to be preserved. The infamous phenomenon of bruxellisation in Brussels, according to which a city is handed over to developers without regard for the urban planning and heritage environment, is a sad example of this [62]. Most immovable heritage legislation in Belgium seeks to counter these effects of passive loss of heritage by enshrining the principle of integrated conservation, according to which heritage should be taken into account in other related public policies. However, this principle of integrated heritage conservation is not always respected in reality and should be further implemented in practice [63]. 
Uniformization and commodification of heritage [64], in the context of a growing globalisation and mass tourism, constitute another risk factor for the destruction of local heritage, and most notably for intangible heritage.

The State may also actively decide to destroy this heritage, or even destroy a much larger slice of cultural heritage that does not fit into its political, ideological or religious vision. The Nazis systematically confiscated and destroyed what they called the Entartete Kunst, i.e. modern art made by Jews, Bolsheviks or other modern artists, in order to impose "heroic art", the official art that favoured the classical canons of beauty. Totalitarian communist regimes have also worked to erase part of the country's history, demolishing palaces of Russian princes or Orthodox churches in the Soviet Empire or wreaking cultural terror during the Chinese Cultural Revolution of 1967-1976, which sought to raze any capitalist vestiges in its path. The destruction of the Buddhas of Bamiyan by the Taliban in Afghanistan in 2001 is another example of selection according to religious criteria of heritage to be protected or not. More recently, Armenian monuments are at risk of being destroyed by the Azeris in the region of Nagorno-Karabakh, although some hope it may be avoided, as "both sides have demonstrated awareness of - and admiration for-heritage that is not their own" [65]. Monuments may then serve as cultural reconciliation after a war or other violent undertakings, and pass from the control of one group to another, such as the Hagia Sophia which was preserved as a mosque after the fall of Constantonople [65].

Nonetheless, there are many examples where the State does not intervene, if at all, as the guardian of cultural heritage and instead seeks to use a policy that destroys heritage, or part of it, to impose an ideological or religious vision on its people. Any vision of a necessarily 'good' state as a guardian of heritage must therefore be subject to critical reflection in order to avoid falling into a dogmatic attempt to see the state as the sole and best guardian of cultural heritage.

Hence the importance of a human rights-based approach to heritage, as it may help to temper the risks of a State monopoly on determining cultural heritage.

\subsection{Human Rights-Based Approach to Cultural Heritage Protection}

As already mentioned, the emergence of the notion of heritage signals a paradigm shift in heritage ethics and, consequently, in heritage law.

Starting in the 1980s, new avenues were explored in the heritage and museum field based on social inclusion, transparency and a form of shared responsibility for heritage. The rights of indigenous peoples to their heritage and land, the claims for restitution of looted, stolen or illegally exported artefacts as well as human remains, indicated an increased attention of the heritage world to these new concerns. To this end, Ireland and Schofield propose to go beyond the 'external' ethics of cultural heritage (professional standards of conservation, etc.) and to open up ethical responsibilities towards the future, in the wake of human rights, social justice and the political economy of heritage [22]. In their view, cultural heritage should be analysed as an intrinsically ethical and political issue as, through heritage, societies shape the meaning of the past in the present and construct a particular vision of their collective 
future. In doing so, the authors are in line with Ricoeur's thinking, which advocates that the work of memory and history has repercussions on the future insofar as "the projection of the future is (effectively) [...] interdependent to the retrospection of past times" [1: 413].

Highlighting the contested nature of heritage, anthropologist Silverman confirms this "Kuhnian paradigm shift toward a socially engaged, politically aware study of the past that regards heritage as contested, recognizes the role of power in the construction of history, focuses on the production of identity, emphasizes representation and performance, and preferentially analyses formerly colonial states and societies and their subaltern populations" [65: 5].

Cultural heritage law also shifted during that time, not only by broadening its scope to embrace a large concept of heritage, but also by considering other rights than the rights in rem, attached to the object or property to be protected. Following a human rights-based approach, an individual and collective right to cultural heritage has slowly emerged in the international and European cenacles, focusing on the access to as well as on the use and enjoyment of heritage. Bidault notes that 'heritage rights' were long absent in international human rights law, but that they come to the surface with the recognition of collective cultural identities and in particular those of minorities and indigenous peoples [67]. Heritage rights became more explicit for intangible heritage and have recently been enshrined as a human right, notably in the Council of Europe Framework Convention on the Value of Cultural Heritage for Society of 2005 (also called the 'Faro Convention'). For the purpose of this paper, the scope will be limited to a brief analysis of this human rights-based approach; a thorough analysis of the conceptualization and operationalization of collective cultural rights at international level has already been conducted in the recent book edited by Andrzej Jakubowksi [68].

Initiated with the 2003 Unesco Convention for the Safeguarding of the Intangible Heritage, the right to cultural heritage has started being expressed. Following the adoption of the Council of Europe Framework Convention on the Value of Cultural Heritage for Society (2005) and Article 23 of the Belgian Constitution, such a right has also been recognised in Belgian law. This evolution confirms the paradigm shift from the right in a thing of (exceptional) cultural value toward the individual and collective right to cultural heritage [69].

The Faro Convention clearly states the right to cultural heritage: "everyone, alone or collectively, has the right to benefit from the cultural heritage and to contribute towards its enrichment" [Article 4, a]. Everyone also has the responsibility to respect the cultural heritage of others, his or her own heritage and the common heritage of Europe.

The influence of human rights is clearly perceptible: "put people and human values at the centre of an enlarged and cross-disciplinary concept of cultural heritage" [Preamble]. It is no longer just a question of cultural heritage law, but also of the right to cultural heritage as "inherent in the right to participate in cultural life" [Article 1]. Safeguarding functions are changing and include, in addition to conservation and protection, digitisation and enhancement of heritage.

This would give rise, through international and European texts, to a right of people (individuals and groups) to cultural heritage. Slowly emerging at the 
outset from the right to participate in cultural life (understood as access to the arts), then extended to the right to cultural life of minorities and indigenous peoples (linked to cultural identity and involving access to resources), and finally recognised as a right to cultural heritage (starting with intangible heritage), this right would be understood as an individual and collective right to access heritage and the benefits deriving from it, including rights of use and collective enjoyment [70]. Furthermore, other fundamental rights, such as the freedom of expression, freedom of religion, the right to information and the right to education, also provide a legal basis for the right of individuals to cultural heritage.

The right to cultural heritage is enshrined in Article 23, point 5 of the Belgian Constitution, guaranteeing "the right to cultural and social fulfilment", just as it can be deduced from point 4 of Article 23 of the Belgian Constitution, "the right to the protection of a healthy environment". This right entails the obligations of the State to respect, protect and fulfil the right to cultural heritage [70]. Analysed as a prerogative recognised to the beneficiaries, the focus of the right to cultural heritage lays on the notion of access.

In her report on cultural rights to the UN in 2011, the independent expert Farida Shaheed identifies the different ways in which access to cultural heritage can be ensured:

(a) physical access to cultural heritage, which may be complemented by access

through information technologies;

(b) economic access, which means that access should be affordable to all;

(c) information access, which refers to the right to seek, receive and impart

information on cultural heritage, without borders; and

(d) access to decision making and monitoring procedures, including administrative and judicial procedures and remedies.

An overlapping principle is non-discrimination, with special attention to disadvantaged groups. [68: 16]

Access, which includes the notions of use and enjoyment, nevertheless varies according to the interest - in the common sense of the term - that the communities or individuals concerned have in it. In the most committed sense, one can find the communities of origin, or "source communities", who consider themselves the custodians or owners of a given cultural heritage (e.g. indigenous people, such as aborigines, Maori etc.), as well as the people who perpetuate a cultural heritage or who are responsible for it (e.g. the "living national treasure" in Japan, designating the custodians of important intangible cultural heritage). Slightly less invested are those individuals and communities, including local communities, who consider the cultural heritage in question to be an integral part of the life of the community but who do not actively contribute to its preservation. Next come experts and artists or craftsmen, who have an interest in accessing the heritage but are not necessarily members of the community. Finally, the most basic level of interest in requesting access to heritage includes the general public.

These different declinations of holders must be taken into account by the State when inviting participation in cultural heritage, not limiting this invitation to the 
public in general, but targeting the participants, in order to "ensure the active involvement of source and local communities, in particular" [68: 17].

Varying degrees of access also implies that some access should be privileged over others, as the interests of individuals and groups vary "according to their relationship with specific cultural heritages" [68: 16]. For example, the local community's access to its cultural heritage, or the religious community's access to its place of worship, would take precedence over that of the general public. Similarly, tourists or researchers wishing to access a monument could not do so to the detriment of the source community of that monument.

Based on the notion of access, the right to cultural heritage would thus include "right of access to and enjoyment of cultural heritage includes the right of individuals and communities to, inter alia, know, understand, enter, visit, make use of, maintain, exchange and develop cultural heritage, as well as to benefit from the cultural heritage and the creation of others" [68: 20]. Access also has a political dimension, bringing it closer to the concept of cultural interest, as the right to cultural heritage also means the "right to participate in the identification, interpretation and development of cultural heritage, as well as to the design and implementation of preservation/safeguard policies and programmes" [68: 20].

The incorporation of the discourse of human rights in the protection of cultural heritage also makes it possible to clarify certain elements contained in heritage conventions and vice versa. Romainville notes that the principle of consultation and participation, inherent to cultural rights and the right to cultural heritage, induces collective procedural rights in these conventions and makes them more effective [70].

The appearance of new provisions, such as the Faro Convention of 2005 and the adoption of Article 23 of the Belgian Constitution, would signal a more assertive willingness to recognise rights for holders of the right to cultural heritage [50].

Still, the enforceability of these human rights to heritage remains weak at the international and European level, except in the case of the appropriation of land by indigenous people as part of their cultural heritage - i.e. through a property right that establishes a strong link between heritage protection and fundamental rights (such as the right to self-determination) - or by analogy in cases of appropriation of intangible cultural heritage. This was confirmed by a recent decision of the European Court of Human Rights where the judge refused to recognise a "universal individual right to the protection of a specific cultural heritage", on the pretext that there is "no 'European consensus' or even any trend among Council of Europe member States, potentially necessitating a reworking of the scope of the rights in question or allowing the Court to infer from the provisions of the Convention" such a universal right. The judge further states that international law, as it currently stands, concerns "cultural rights of national minorities and the right of indigenous people to conserve, control and protect their cultural heritage" and is limited to the specific status of individuals [ECHR, Ahunbay and Others v. Turkey decision no 6080/06 of 29 January 2019, $\S 25$ and $\S \S 23-24]$. In so doing, the judge seems to have disregard the Faro Convention, which has admittedly not been signed by Turkey, but which has entered into force within the Council of Europe, and therefore reflects a tendency to recognise such a universal right. At the same time, it seems difficult to infer from the Convention a fundamental right to protection of heritage; the applicants had 
based it on Article 8 of the Convention (protection of privacy) and not on Article 10 (freedom of access) as in the Akdas judgment [ECHR, Akdas v. Turkey decision no 41056/04 of 16 February 2010].

At the Belgian level, article 23 of the Constitution also suffers from a lack of enforceability. The standstill principle, implying that whenever the lawmaker adopts protective measures he cannot go back (unless for imperative reasons which have to be justified),[72] can however already provide some degree of enforceability, as has been shown for the right to cultural heritage [50].

The human rights-based approach allows the legal recognition of other stakeholders than the State in the protection of cultural heritage, providing them with a collective human right to access (and also to the use and enjoyment of) cultural heritage. However, this right is still lacking in enforceability, one reason being the difficulty to determine stakeholders (citizens, the public, the community, groups, associations, ...) and another regarding the rules of admissibility of actions, that often limit access to justice to these collective stakeholders [50].

\section{Dealing with Belgium's Colonial Heritage}

Heritage conservation requires that the State protects cultural identities of its entire population, for the past, present and future. But the State could draw its heritage policy and regulation in a way that serves its own political, ideological or religious agenda, by consciously or unconsciously erasing pages of its history or overplaying others. This becomes particularly problematic when cultural minorities have no voice or when the multiple facets of a cultural identity — which has become much more complex and diverse than the national identity intended by 19th century nation-states - are not heard.

Belgium's colonial heritage offers a striking example of the complexity of such a task: make sure to adopt the 'right' approach to deal with contested heritage. After having analysed the existing legal framework for cultural heritage in Belgium and having examined potential risks of a heavy State-controlled heritage policy, it is important to look how certain Belgian lawmakers think of the right way to deal with this darker part of our history.

At this current time, political intervention (and some form of regulation) on colonial heritage is taking place in two main areas: the restitution of colonial collections and the decolonisation of colonial symbols in the public space.

First, the restitution of colonial collections received political attention in the wake of the French Report on Restitution of African Heritage, issued in November 2018 by Sarr and Savoy,[73] and with the reopening of the AfricaMuseum in Tervuren, the former colonial museum in December 2018. Several parliamentary resolutions were adopted in 2019. These resolutions called for dialogue and the setting up of working groups. They do not have a binding force, but signal a potential policy shift on these matters, which eventually leads to a new legal framework.

The Federal Parliament adopted a resolution on 14 ${ }^{\text {th }}$ of March 2019 concerning "translocated" works of art [Résolution du 14 mars 2019 de la Chambre relative aux ouvres d'art «translocalisées » et à l'entame d'un dialogue avec l'État français, 
Doc. Parl., Ch., 2018-2019, no 2847/012], requiring not only to receive some artwork back from France after it was taken during the French Revolution, but also asking for an inventory and analysis of objects from Central Africa in Belgian museums, the setting up of an interdisciplinary working group with Belgian, European and African experts to work on statutes and conditions for the acquisition of these assets and the organisation an international conference.

In the Brussels Region, two resolutions were adopted in the same period, which exclusively focused on the restitution of human remains and cultural goods from the colonial period [Résolution du Parlement bruxellois francophone du 29 mars 2019 concernant la restitution des restes humains et des biens culturels issus de la période coloniale, Doc. parl., 2018-2019, 126/1; Résolution du Parlement de la Région de Bruxelles-Capitale du 30 avril 2019 relative aux biens culturels et patrimoniaux africains et à la restitutions des restes humains situés sur le territoire bruxellois, Doc. parl., RBC, 2018-2019, A-785/1]. Both of these resolutions call for the creation of a multidisciplinary group of experts with Belgian, African and diaspora members working on the notion of "ill-gotten" goods ("biens mal acquis"). In these resolutions also appeared the necessity of setting up an inventory of cultural objects and human remains; of finding ways, means and forms of restitution with a priority for human remains; of drafting guidelines for the decolonisation of public collections; of organising a major international conference with African and diaspora representatives; and of creating a foundation to study and enhance colonial archives. The members of the Brussels' Parliament finally insisted on cooperation at the federal level, as the Federal State is still competent for federal museums, such as the AfricaMuseum and the Royal Belgian Institute of Natural Science.

Despite these resolutions, to date no working group has officially been set up yet and no concrete restitution has been made of colonial collections. Nonetheless, the French Community ordered an academic report on the restitution of non-European collections (although there are not that many that fall under its jurisdiction) which will be finalised in the autumn of 2020. The Federal Agency for Scientific Policy, BELSPO, has also financed a research project on non-European human remains, Human Remains Origin(s) Multidisciplinary Evaluation (HOME), for 2020-2022, with seven partners. Finally, as previously mentioned, the Federal Parliament just launched a commission on colonial history, where the restitution question is also examined.

The second area of intervention for colonial heritage concerns the colonial symbols in the public space. Since several months, debates, protests and actions have taken place all over the world, under the impulse of the Black Lives Matter movement. They prompted lawmakers and governments to react, some hearing the claim of racial justice, others fearing the cry of iconoclasm. In Belgium, public and political reactions were diverse too, but recent parliamentary resolutions indicate a clear political will to seriously reflect on these colonial symbols (monuments, statutes, street names...) in our public spaces.

For the moment, the Brussels Parliament adopted the resolution on 17 July 2020 on structural and inclusive decolonisation of the public space through dialogue and remembrance, [Résolution du Parlement de la Région de Bruxelles-Capitale du 17 juillet 2020 relative à la décolonisation structurelle et inclusive de l'espace public 
bruxellois dans le cadre d'un travail de dialogue et de mémoire, Doc. Parl, RBC, 2019-2020, nr. A-192/4] requiring, inter alia, a complete inventory of the colonial symbols in Brussels's public spaces and the creation of a working group representing Brussels' diversity. This group will formulate concrete recommendations, after an inclusive dialogue about the place and the treatment of these colonial remnants in Brussels, as well as accompany the local authorities in these undertakings, fostering the promotion of a plurality of memories and a feminisation of the public space. Moreover, the resolution discusses the several options for a case by case analysis, i.e. add an explanatory plate to the monument or statue, erect a "countermonument" or "counterstatue" from a contemporary artist, change street names to honour resistants to colonialism, remove the symbol and put it in a museum, create a specific museum for colonisation, etc.

On July 13th 2020, the Brussels Secretary of State for cultural heritage launched an open call for participating in a working group, which will be composed of academic experts and members of the civil society, including the diaspora from the former Belgian colonies (Democratic Republic of Congo, Rwanda, Burundi), as well as representatives of Brussels's municipalities, and which will be mandated to report on these questions [74]. This group will start working in November 2020, with a final report expected in 2021.

The Flemish region followed a different approach and decided to frame it as a local competence, as it seemed more fitting to decentralise this matter and respect the local autonomy. The Flemish Minister for local authorities took initiative by setting up a group of five experts who helped draft guidelines for local authorities dealing with such symbols. The very recent manual can be found on the website of the Agency of Integration and civic integration, together with useful links for citizen participation, best practices domestic and abroad, arguments in the current debate or mapping colonial symbols in one's municipality [75].

Answering a parliamentary question in June 2020, the Flemish Minister for Immovable Heritage shared his vision on this topic. This included statements such as the wish to broaden and contextualise the narrative around heritage to avoid glorification of this darker side of our history and to realise that "heritage is never neutral"; to leave heritage in the public space because it is part of our streetscape and these stories are also told from there; and not to delist nor remove the protected elements of colonial heritage; conduct further research even though an inventory of this darker heritage seems unfeasible; and finally to call for a social debate on how to give meaning and to deal with heritage [Questions nr 2552 and 2626 answered on 18 June 2020 at the Commission of Housing and Immovable Cultural Heritage: https://www.vlaamsparlement.be/commissies/commissievergaderingen/1399650/ verslag/1403844, Accessed on 30 September 2020] However, no concrete action followed this discourse, except a link on the website of the Agency of Integration,[76] and the current legal framework for heritage in Flanders does not provide much room for social debate.

Although it is still too early to draw conclusions from these recent evolutions, it seems quite clear they will-to some degree, and depending on the competent political entity (Federal Sate, region or community)_result in specific policy and regulatory measures. It is about time to shed some light on this contested 
heritage, hopefully by adopting a human rights-based and inclusive approach as it seems the fairest way to deal with this dark past.

\section{Conclusion}

Does the law determine what heritage to remember? Several conclusive remarks can be drawn from this starting question.

First, regulation plays a prominent role in the protection of cultural heritage. Through legal measures adopted by the competent public authorities, these authorities elaborate their policy on what heritage should be protected. They have the sovereign power to do so, including for properties which are not their own. In other words, the law drafted by these public authorities set the framework within which heritage can be protected and therefore determined. As was analysed in Belgian law, the legal scope of what is considered worthy of protection has extended over the years, by providing broad definitions and enumerating extensive interests for tangible heritage. However, this enlarged legal vision on what is regarded as heritage does not preclude heritage from certain risks in practice: the risk of being (un)consciously forgotten, the risk of being abandoned or the risk of being destroyed, as some concrete examples in Belgium and elsewhere have shown. These risks concerning heritage can in turn also impede, manipulate or force individual and collective memory, as analysed from Ricoeur's work.

Second, the law itself can provide for an inclusive approach for the determination of cultural heritage, by integrating other actors than the competent public authorities to the process. The importance of participative governance has been highlighted in studies and reports, but it is not yet sufficiently implemented in the examined Belgian legislations. The power to decide and control what heritage to protect remains in the hands of the State, which is not surprising as the State also acts as the ultimate guardian of heritage. However, a more integrated and participative approach — also based on the human right to cultural heritage — could recognise the diversity of cultural identities and help deal with darker parts of our heritage, such as Belgian's colonial history. Moreover, it would share the responsibility for heritage [77].

Finally, the protection of cultural heritage, in a similar manner as historical knowledge, aims to find a balance between remembering and forgetting traces of the past. Not everything can be protected nor can everything be erased. This difficult balance shifted the last decades, taking much more aspects of the past into consideration as part of a people's heritage, in order to recognise the complexity and the multiplicity of cultural identities. There is no univocal identity narrative, told through selected items to be protected as part of a national or universal heritage, but rather a variety of cultural heritages which forms the richness of individual and collective identity. This paradigm shift also operated in cultural heritage law, as has been demonstrated, but there is still much to be done to effectively implement a collective right to cultural heritage, and to include the variety of stakeholders for the determination and protection of cultural heritage. 
Open Access This article is licensed under a Creative Commons Attribution 4.0 International License, which permits use, sharing, adaptation, distribution and reproduction in any medium or format, as long as you give appropriate credit to the original author(s) and the source, provide a link to the Creative Commons licence, and indicate if changes were made. The images or other third party material in this article are included in the article's Creative Commons licence, unless indicated otherwise in a credit line to the material. If material is not included in the article's Creative Commons licence and your intended use is not permitted by statutory regulation or exceeds the permitted use, you will need to obtain permission directly from the copyright holder. To view a copy of this licence, visit http://creativecommons.org/licen ses/by/4.0/.

\section{References}

1. Ricoeur, Paul. 2000. La Mémoire, l'histoire, l'oubli. Paris: Seuil.

2. Thomas, Suzie, Vesa-Pekka Herva, Oula Seitsonen, and Eerika Koskinen-Koivisto. 2019. Dark Heritage. In Encyclopedia of Global Archaeology, ed. C. Smith, 1-11. Cham: Springer International Publishing. https://doi.org/10.1007/978-3-319-51726-1_3197-1.

3. European Year of Cultural Heritage. 2020. Text. European Year of Cultural Heritage - European Commission. european-year-cultural-heritage_en.html. Accessed September 29.

4. Freud, Sigmund. 1990. Beyond the Pleasure Principle. Translated by James Strachey. The Standard Edition. New York: W. W. Norton \& Company.

5. Freud, Sigmund. 1920. Jenseits des Lustprinzips.

6. The Slave Route. 2020. UNESCO.

7. Lowenthal, David. 1985. The Past is a Foreign Country. Cambridge University Press.

8. Todorov, Tzvetan. 1995. Les abus de la mémoire. Paris: Arléa-Le Seuil.

9. Lowenthal, David. 2015. The Past is a Foreign Country - Revisited. Cambridge University Press.

10. Bertrams, Kenneth, and Pierre-Olivier de Broux. 2007. Du négationnisme au devoir de mémoire: l'histoire est-elle prisonnière ou gardienne de la liberté d'expression? Revue de droit de l'ULB 35: 75-134.

11. Nietzsche, Friedrich. 1874. On the Use and Abuse of History for Life. Wikisource: Translated by Adrian Collins.

12. Nietzsche, Friedrich. 2017. Writings of Nietzsche: Volume III. In Woodstock, ed. Anthony Uyl. Ontario: Devoted Publishing.

13. Moonen, Tom. 2015. Constitutionalism and heritage protection in South Africa: the story of Constitutional Hill. In Liber amicorum Anne Mie Draye, ed. Johan Ackaert, Alexander De Becker, and Petra Foubert, 33-45. Antwerpen: Intersentia.

14. National Memorial Fort Breendonk. 2020. http://www.breendonk.be/EN/index.asp. Accessed September 28.

15. Truyts, Joris. 2020. Christophe Busch (ex-Dossin) gaat Hannah Arendt Instituut leiden, nieuw centrum rond diversiteit en burgerschap. vrtnws.be, May 27.

16. Braeckman, Colette. 2020. RD Congo: un démarrage chaotique pour la commission Décolonisation. Le Soir Plus, July 31.

17. Rutazibwa, Olivia U. 2020. "Congo" Commissie - why I will not participate in the expert group [NL/ENG].//Olivia U. Rutazibwa.

18. Collectif de 60 historiens belges. 2020. Les historiens s'interrogent sur la constitution et les amalgames de la Commission "Congo." LaLibre.be, August 20, sec. debats.

19. Collectif d'historiens belges. 2020. «Commission Congo: la peur paralysante de l'historien». Le Soir Plus, August 24.

20. Grymonprez, Simon. 2020. Diaspora zet Congocommissie meteen onder hoogspanning. De Standaard, July 13, sec. Binnenland.

21. Vidal, Koen. 2020. Bijzondere Congocommissie belooft diaspora uitgebreid te raadplegen. De Standaard, sec. Binnenland. https://www.standaard.be/cnt/dmf20200713_97681773. Accessed October 20.

22. Ireland, Tracy, and John Schofield. 2015. The Ethics of Cultural Heritage. In The Ethics of Cultural Heritage, ed. Tracy Ireland and John Schofield, 1-10. Ethical Archaeologies: The Politics of Social Justice 4. Springer New York. https://doi.org/10.1007/978-1-4939-1649-8_1. 
23. Smith, Laurajane. 2006. Uses of Heritage, New ed. London, New York: Routledge.

24. Handler, Richard, and Eric Gable. 1997. The new history in an old museum: creating the past at Colonial Williamsburg. Durham: Duke University Press.

25. Chastel, André, and Jean-Pierre Babelon. 1994. La notion de patrimoine, 2nd ed. Paris: Liana Levi.

26. Arendt, Hannah. 1961. The Crisis in Culture. Between Past and Future. New York: Viking.

27. Choay, Françoise. 1999. L’Allégorie du patrimoine. Édition: Nouv. éd. rev. et corr. Paris: Seuil.

28. Leniaud, Jean-Michel. 2009. Patrimoine. Encyclopadia Universalis [en ligne].

29. Desvallées, André. 1995. Emergence et cheminements du mot patrimoine 3: 6-29.

30. Desvallées, André. 2003. De la notion privée d'héritage matériel au concept universel et extensif de patrimoine: retour sur l'histoire et sur quelques ambiguïtés sémantiques. In Médias et Patrimoine, ed. Martine Cardin, 19-35. Québec: Université de Laval/UNESCO.

31. Frigo, Manlio. 2004. Cultural property v. cultural heritage: A "battle of concepts" in international law? IRRC 86: 367-378.

32. Prott, Lyndel V., and Patrick J. O'Keefe. 1992. 'Cultural Heritage' or 'Cultural Property'? International Journal of Cultural Property 1: 307-320. https://doi.org/10.1017/S094073919200033X.

33. Wozny, Danièle, and Barbara Cassin (eds.). 2016. Les intraduisibles du patrimoine en Afrique subsaharienne. Les intraduisibles du patrimoine en Afrique subsaharienne. Quaero. Paris: Demopolis.

34. Ost, François. 1998. Un héritage sans testament. Patrimoine et générations futures. Journal des procès: $16-19$.

35. Cornu, Marie, Jérôme Fromageau, and Catherine Wallaert (eds.). 2012. Dictionnaire comparé du droit du patrimoine culturel. Paris: CNRS Éditions.

36. de Clippele, Marie-Sophie. 2020. Le patrimoine culturel immobilier en Région wallonne. Guide de droit immobilier 92: 191-250.

37. de Clippele, Marie-Sophie, Jean-François Neuray, and Michel Quintin (eds.). 2020. Évolutions récentes dans la protection du patrimoine. Bruxelles: Larcier.

38. Vandenhende, Lise. 2020. De beschermingswaardigheid van onroerend erfgoed: naar sterkere bindende criteria. Gent: Universiteit van Gent.

39. Heinich, Nathalie. 2009. La fabrique du patrimoine: de la cathédrale à la petite cuillère. Ethnologie de La France 31. Paris: Maison des sciences de l'homme.

40. Postgebouw, Oostende. 2020. https://inventaris.onroerenderfgoed.be/erfgoedobjecten/55465. Accessed September 28.

41. Villa Le Pangolin, Knokke-Heist. 2020. https://inventaris.onroerenderfgoed.be/erfgoedobjecten 158812. Accessed September 28.

42. Klooster Mariazusters van Franciscus, bezinningscentrum Abdij Roosenberg, Waasmunster. 2020. https://inventaris.onroerenderfgoed.be/erfgoedobjecten/88546. Accessed September 28.

43. Bories, Clémentine. 2011. Le patrimoine culturel en droit international: Les compétences des Etats à l'égard des éléments du patrimoine culturel. Paris: Editions A. Pedone.

44. Wagener, Noé. 2014. Les prestations publiques en faveur de la protection du patrimoine culturel. Thèse de doctorat, France: Université de Paris-Sud.

45. Sambon, Jacques. 2005. Le droit de pétition et le déclenchement de procédures par le public: de la participation réactive à la participation proactive. In La participation du public au processus de décision en matière d'environnement et d'urbanisme, ed. Benoît Jadot. Bruxelles: Bruylant.

46. Delnoy, Michel. 2007. La participation du public en droit de l'urbanisme et de l'environnement. Droit immobilier. Bruxelles: Larcier.

47. Ost, François. 1995. La responsabilité, fil d'Ariane du droit de l'environnement. Droit et société: 281-322.

48. Union, Publications Office of the European. 2018. Participatory governance of cultural heritage : report of THE OMC (Open Method of Coordination) working group of Member States' experts. Website. April 18.

49. Balen, K. van, Aziliz Vandesande, and Raymond Lemaire International Centre for Conservation, ed. 2015. Community involvement in heritage. Reflections on Cultural Heritage Theories and Practices. Antwerpen: Garant.

50. de Clippele, Marie-Sophie. 2020. La dimension collective du patrimoine culturel : la nature et les prérogatives des acteurs du collectif. Perspectives de droit belge. Revue de Droit de l'Université de Sherbrooke 49. 
51. Wagener, Noé. 2012. Personnes publiques et protection du patrimoine : approche juridique. In Le patrimoine, oui, mais quel patrimoine?, ed. Chérif Khaznadar, 107-125. Internationale de l'imaginaire N.s., 27. Arles: Actes Sud Editions.

52. Cornu, Marie, and Noé Wagener. 2018. L'objet patrimoine, Une construction juridique et politique? Vingtième Siècle. Revue d'histoire No 137: 33-47.

53. Del Pozo, Paz Benito, and Pablo Alonso Gonzalez. 2012. Industrial Heritage and Place Identity in Spain: From Monuments to Landscapes. Geographical Review 102. [American Geographical Society, Wiley]: 446-464.

54. Turhalli, Zeynep. 2014. Le droit au patrimoine culturel face aux révolutions. La Revue des droits de l'homme. Revue du Centre de recherches et d'études sur les droits fondamentaux.. https://doi. org/10.4000/revdh.998.

55. Dumont, Hugues. 1996. Le pluralisme idéologique et l'autonomie culturelle en droit public belge. 1: De 1831 à 1970. Vol. 1. Publications Des Facultés Universitaires Saint-Louis 68. Bruxelles: FUSL.

56. Gellner, Ernest. 1983. Nations and Nationalism. Oxford: Blackwell Publishers.

57. Hobsbawm, Eric. 2001. Nations et nationalisme depuis 1780: Programme, mythe, réalité. Translated by Dominique Peters. Paris: Folio.

58. Hottin, Christian. 2008. Une nouvelle perception du patrimoine. Edited by Christian Hottin. Le patrimoine culturel immatériel 116-117. Culture et Recherche: 15.

59. Blake, Janet. 2009. UNESCO’s 2003 Convention on Intangible Cultural Heritage. The implications of community involvement in "safeguarding." In Intangible Heritage, ed. Laurajane Smith and Natsuko Akagawa, 45. Abingdon: Routledge.

60. Hafstein, Valdimar Tr. 2015. Célébrer les différences, renforcer la conformité. In Le patrimoine culturel immatériel : Enjeux d'une nouvelle catégorie, ed. Chiara Bortolotto, tran. Olivier Morin, 75-97. Ethnologie de la France. Paris: Éditions de la Maison des sciences de l'homme.

61. Europe for Citizens Map - Project: "PUnCH: Participation of UNderrepresented citizens for the valorization of the Cultural Heritage.” 2020. https://ec.europa.eu/programmes/europe-for-citizens/proje cts/efc-project-details-page/?nodeRef=workspace://SpacesStore/a3e9ee4d-7f26-42a3-b01a-aae57 4d2d7ff. Accessed September 30.

62. Demouveaux, Jean-Pierre. 2015. La Bruxellisation. In D'urbanisme et d'environnement - Liber Amicorum Francis Haumont, ed. Charles-Hubert Born and François Jongen, 149-160. Bruxelles: Bruylant.

63. Aerts, S. 2018. De uitbouw van een adequaat juridisch kader voor bescherming en beheer van cultureel erfgoed als proeve van een geïntegreerd omgevingsrecht. Doctorat, Bruxelles: KULeuven.

64. Boltanski, Luc, and Arnaud Esquerre. 2017. Enrichissement: une critique de la marchandise. NRF Essais. Paris: Gallimard.

65. Eakin, Hugh. 2020. Opinionl When an Enemy's Cultural Heritage Becomes One's Own. The New York Times, November 30, sec. Opinion.

66. Silverman, Helaine. 2020. (2011) Contested Cultural Heritage. A Selective Historiography. https ://www.academia.edu/5220200/_2011_Contested_Cultural_Heritage_A_Selective_Historiography. Accessed September 22.

67. Bidault, Mylène. 2009. La protection internationale des droits culturels. Collection Du Centre Des Droits de l'homme de l'Université Catholique de Louvain v. 10. Bruxelles: Bruylant.

68. Jakubowski, Andrzej (ed.). 2016. Cultural Rights as Collective Rights: An International Law Perspective. Cultural Rights as Collective Rights. Leiden: Brill Nijhoff.

69. Cornu, Marie. 2013. Propriété et patrimoine, entre le commun et le propre. In Pour un droit économique de l'environnement. Mélanges en l'honneur de Gilles J. Martin, 145-161. Editions Frison-Roche.

70. Romainville, Céline. 2014. Le droit à la culture, une réalité juridique - Le régime juridique du droit de participer à la vie culturelle en droit constitutionnel et en droit international. Bruxelles: Bruylant.

71. Shaheed, Farida. 2011. Report of the independant expert in the field of cultural rights. A/ HRC/17/38. United Nations General Assembly.

72. Hachez, Isabelle. 2008. Le principe de standstill dans le droit des droits fondamentaux: une irréversibilité relative. 1. éd. Human Rights $=$ Menschenrechte $=$ Droit de l'Homme 8 . Athènes: Sakkoulas.

73. Sarr, Felwine, and Bénédicte Savoy. 2018. Restituer le patrimoine Africain. Paris: Philippe Rey. 
74. Lancement d'un groupe de travail sur la présence des symboles coloniaux dans l'espace public urban.brussels. 2020. http://urban.brussels/lancement-dun-groupe-de-travail-sur-la-presence-dessymboles-coloniaux-dans-lespace-public/. Accessed September 30.

75. Koloniale verwijzingen in de publieke ruimte. 2020./en/node/2143. Accessed December 7.

76. Erfgoed in kaart. 2020./erfgoed-in-kaart. Accessed October 26.

77. de Clippele, Marie-Sophie. 2020. Protéger le patrimoine culturel : à qui incombe la charge?. Brussels: Presses de 1'Université Saint-Louis.

Publisher's Note Springer Nature remains neutral with regard to jurisdictional claims in published maps and institutional affiliations. 